\title{
Pengembangan Pariwisata Bertema Eco-Forest dan Sungai di Bumi Perkemahan Tangsi Jaya
}

\author{
Beta Budisetyorini', Deddy Adisudharma², Mega Fitriani Adiwarna Prawira3 ${ }^{3}$ Dicky \\ Arsyul Salam ${ }^{4}$, Wisi Wulandari ${ }^{5}$, Eko Susanto ${ }^{6 *}$ \\ Sekolah Tinggi Pariwisata Bandung 1,2,3,4,5 \\ Politeknik Negeri Bandung ${ }^{6}$ \\ Email: eko.susanto@polban.ac.id
}

\begin{abstract}
Tourism development that is on an alternative route generally experiences several obstacles in its development due to problems in spatial patterns related to accessibility and natural physical spatial planning and spatial planning of tourism activities and facilities related to sustainable tourism considerations. Tangsi Jaya Camping Ground which is located on the alternative route Ciwidey-Cianjur has the potential for camping tourism which is unique in its natural attractions of forests, villages, rice fields and rivers with the dominance of local visitors and domestic tourists. This research aims to examine the development of camping ground tourism through a descriptive-qualitative approach to spatial aspects, spatial patterns and spatial planning of tourism activities and facilities based on the concept of Eco Forest Tourism, River Tourism and natural physical spatial planning. This research has resulted in an image mapping of spatial patterns, as well as the layout of activities and tourism facilities for the Tangsi Jaya campground that consider sustainable tourism. It is hoped that the application of the results of this research can serve as a direction for the development plan for the development of the Tangsi Jaya Camping Ground for local managers with the hope that the tourism sector can provide a multiplier effect of sustainable tourism both for increasing regional income and equal distribution of income for the people of West Bandung, Ciwidey, Cianjur Regency in the future.
\end{abstract}

Keywords: camping ground; ecotourism; tourism destinations; sustainable tourism.

\begin{abstract}
Abstrak
Pengembangan wisata yang berada di jalur alternatif pada umumnya mengalami beberapa kendala dikarenakan permasalahan pola ruang terkait aksesibilitas serta tata ruang fisik alam, tata ruang aktivitas dan fasilitas wisata terkait pertimbangan pariwisata berkelanjutan. Bumi Perkemahan Tangsi Jaya terletak di jalur alternatif Ciwidey-Cianjur memiliki potensi wisata perkemahan dengan keunikan daya tarik wisata alam hutan, pedesaan, persawahan dan sungai dengan dominasi pengunjung lokal dan domestik. Penelitian bertujuan mengkaji pengembangan wisata bumi perkemahan melalui pendekatan deskriptif-kualitatif pada aspek spasial, pola ruang serta tata ruang aktivitas dan fasilitas wisata berdasarkan konsep Eco Forest Tourism, River Tourism dan tata ruang fisik alam. Penelitian ini telah menghasilkan gambar pemetaan pola ruang, serta tata letak aktivitas dan fasilitas wisata bumi perkemahan Tangsi Jaya yang mempertimbangkan pariwisata berkelanjutan. Penerapan hasil penelitian ini diharapakan dapat menjadi arahan rencana pengembangan pembangunan Bumi Perkemahan Tangsi Jaya bagi para pengelola setempat dengan harapan sektor pariwisata dapat memberikan multiplier effect pariwisata berkelanjutan baik bagi peningkatan pendapatan daerah maupun pemerataan pendapatan masyarakat Kabupaten Bandung Barat, Ciwidey, Cianjur di masa yang akan datang.
\end{abstract}

Kata Kunci: bumi perkemahan; ekowisata; destinasi pariwisata; pariwisata berkelanjutan.

\section{A. PENDAHULUAN}

Kabupaten Bandung Barat merupakan wilayah di Provinsi Jawa Barat dengan berbagai potensi pariwisata berbasis alam dan budaya. Dari sekian banyak potensi pariwisata yang dimiliki Kabupaten Bandung Barat tidak dapat secara serentak dibangun dan dikembangkan sebagai destinasi wisata. Potensi 
destinasi wisata perlu digali, dilindungi, dikelola dan dimanfaatkan secara terencana, terpadu, dan berkesinambungan guna mendapatkan nilai daya saing yang berkelanjutan (Cracolici \& Nijkamp, 2009).

Mengingat sektor pariwisata merupakan salah satu core economy yang dapat memberikan multiplier effect baik bagi peningkatan Pendapatan Asli Daerah (PAD) maupun pemerataan pendapatan masyarakat setempat (Jacobsen, Lester, \& \& Halpern, 2014), maka salah satu destinasi wisata yang terletak di jalur alternatif Ciwidey - Cianjur yaitu Bumi Perkemahan Tangsi Jaya (Bumi Perkemahan Tangsi Jaya) ditetapkan sebagai bagian dari 10 destinasi wisata baru Kabupaten Bandung Barat.

Bumi Perkemahan Tangsi Jaya memiliki potensi wisata perbukitan hijau dengan pemandangan alam hutan, pedesaan, persawahan, dan sungai yang perlu dikembangkan pada aspek atraksi wisata, amenitas serta aksesibilitasnya dalam upaya meningkatkan daya saing produk wisata (Cimbaljević, Stankov, \& \& Pavluković, 2019), kualitas pelayanan (Lo, Chin, \& Law, 2019) (Zatori, Smith, \& Puczko, 2018), pengalaman berwisata (Karayilan \& Cetin, 2016) dan jumlah kunjungan wisatawan (Beritelli \& Laesser, 2017) untuk mewujudkan pengembangan wisata perkemahan yang berkelanjutan yang mempertimbangkan kelestarian lingkungan alam, sosial budaya serta pemerataan peningkatan pendapatan ekonomi masyarakat sekitar Kabupaten Bandung Barat, Ciwidey dan Cianjur.

Data penelitian menunjukkan permasalahan pengembangan di Bumi Perkemahan Tangsi Jaya antara lain aksesibilitas yang berada pada jalur alternatif Ciwidey-Cianjur yang belum banyak dikenal masyarakat regional. Permasalahan lain adalah kurangnya penawaran pengalaman berwisata yang aman dan nyaman akibat pola dan penataan ruang berbasis aktivitas dan fasilitas wisata belum terintegrasi dengan kondisi fisik alam. Hal ini diyakini memberikan dampak sulitnya pengembangan Bumi Perkemahan Tangsi Jaya sebagai destinasi wisata sebagaimana hasil studi (Romão, Neuts, Nijkamp, \& Shikida, 2007) yang menyatakan ketidaksesuaian antara ekspektasi yang diciptakan oleh pengunjung berdasarkan informasi tentang obyek wisata dan tingkat kepuasan pengalaman ketika berkunjung dapat menjadi faktor kuat ketidakpuasan, dengan implikasi negatif untuk kemungkinan rekomendasi.

Berdasarkan kondisi tersebut, penelitian mengkaji pengembangan wisata bumi perkemahan melalui pendekatan spasial, pola ruang serta tata ruang aktivitas dan fasilitas wisata dengan tema eco forest tourism (Zhu, et al., 2015) dan river tourism (Prideaux \& Cooper, 2009). Penelitian ini berupaya memberikan gambar pemetaan pola ruang, tata letak aktivitas dan fasilitas wisata bumi perkemahan dengan adopsi prinsip pariwisata berkelanjutan. Hasil penelitian ini diharapkan menjadi arahan rencana pengembangan pembangunan Bumi Perkemahan Tangsi Jaya bagi para pengelola setempat.

\section{B. LITERATUR REVIEW}

\section{Ekowisata Hutan}

Pengembangan pariwisata di kawasan yang sensitif secara ekologis tidak hanya membutuhkan sumber daya lingkungan untuk menghasilkan pengalaman pariwisata, tetapi juga tergantung, dalam jangka panjang, pada pelestarian (Williams \& Ponsford, 2009). UNWTO memberikan rekomendasi perhatian tegas pada pengembangan pariwisata berkelanjutan (UNWTO, Seminar on Tourism Sustainability and Local Agenda 21 in Tourism, 2006) dan memberikan definisi hubungan yang jelas antara daya saing dan keberlanjutan pariwisata: "to compete effectively destinations, have to deliver excellent value to visitors. This depends on many aspects working together in unity. From the time that the visitor arrives at the destination, until he/she leaves, visitor value is affected by many services and experiences including a range of public and private services, community interactions, environment and hospitality" (UNWTO, Practical Guide to Tourism Destination Management, 2007: 9).

Dari perspektif pariwisata, hutan memiliki fungsi yang semakin penting sebagai lahan rekreasi, secara berjenjang memberikan berbagai manfaat bagi masyarakat dan mendukung pariwisata pedesaan

2 | Jurnal Kepariwisataan: Destinasi, Hospitalitas dan Perjalanan, Volume 5 Nomor 1, 2021: 75-88 
dan pembangunan ekonomi (Murphy, 2006). Pengembangan wisata hutan memiliki variasi yang luas, mulai dari jalur rintisan yang sederhana bagi masyarakat lokal hingga pembangunan skala penuh yang terdiri dari fasilitas yang paling umum digunakan (misalnya rute berjalan kaki, papan nama, fasilitas piknik, parkir mobil) dan fasilitas yang lebih luas (misalnya pusat pengunjung, restoran / kafe, penyediaan akomodasi) (Lee, Huang, \& Yeh, 2010).

Untuk memilih hutan potensial sebagai tempat rekreasi, (Hsueh \& Lai, 2000) mengidentifikasi tiga jenis sumber daya sebagai kriteria: aset alam, atraksi buatan dan prasarana pendukung pariwisata. Aset alam terjadi secara alami dan dianggap berharga dalam bentuk aslinya, termasuk berbagai macam flora dan fauna, air terjun spektakuler dan pemandangan hutan, khusus fitur topografi dan geologi serta fenomena iklim. Atraksi buatan manusia adalah bangunan yang menarik minat wisatawan dan memiliki nilai sejarah dan budaya yang tinggi, seperti jembatan, terowongan, waduk, jalan setapak, situs arkeologi, tugu peringatan, monumen, dan rel kereta api hutan.

Infrastruktur pendukung pariwisata dapat mengacu pada berbagai layanan dan fasilitas komersial yang ditawarkan kepada pengunjung memenuhi kebutuhan hidup sehari-hari mereka. Mereka dapat dibagi lagi menjadi lima kategori: fasilitas kenyamanan umum (misalnya toilet, kursi, meja), fasilitas rekreasi, berorientasi pendidikan. fasilitas, penyediaan transportasi, makanan dan minuman serta akomodasi yang tersedia untuk itu penggunaan pengunjung.

Berdasarkan pembahasan di atas bahwa daya tarik destinasi berbasis hutan ditentukan oleh atribut uniknya, termasuk keanekaragaman sumber daya alam, keanekaragaman aset budaya dan sejarah, ketersediaan infrastruktur pendukung pariwisata dan penyediaan layanan informasi dan fasilitas kenyamanan (Lee, Huang, \& Yeh, 2010).

\section{Ekowisata Sungai}

Sejak awal kehidupan manusia, sungai berperan besar dalam kehidupan, peradaban, dan pembangunan ekonomi. Pada mulanya, sungai selain untuk memfasilitasi transportasi jarak dekat, dan jauh, menawarkan juga kemungkinan untuk berdagang dan berburu bagi manusia (Conway, 2002). Sungai sangat mempengaruhi proses revolusi industri dimasa lampau, menjadi salah satu sumber daya alam utama saat industri berpindah dari pusat perkotaan dan serta untuk memenuhi kebutuhan rekreasi (Cooper \& Prideaux, 2005).

Fitur utama sungai yang menjadi dasar pembentukan kegiatan pariwisata adalah nilai estetika, pesona alam dan peran sebagai koridor transit dan transportasi (Prideaux \& Cooper, River Tourism, 2009). Karena sifat ekosistem zona ekowisata sungai yang rapuh, pengaturan pengembangan ekowisata harus menjunjung tinggi prinsip-prinsip: 1) menyebabkan kerusakan paling sedikit pada lingkungan ekologi; 2) memungkinkan wisatawan untuk berpartisipasi kegiatan penelitian, mudah dikendalikan dan dikelola; serta 3) kembali ke dan memahami alam sekaligus memperkuat kesadaran untuk melindungi lingkungan (Jianxiong, Z. Pei, \& Lu, 2014).

\section{Konsep Pola Ruang Dan Tata Ruang Pariwisata}

Penerapan pola ruang dan tata ruang untuk pengembangan wisata alam, dalam hal ini untuk wisata perkemahan mempertimbangkan komponen sebagai berikut (Wahid \& SH, 2016). 1) Fisik Alam: Terdiri dari topografi, klimatologi, geologi, hidrologi yang mendukung pengembangan Bumi Perkemahan Tangsi Jaya sebagai destinasi wisata; 2) Tata Guna Lahan / Fungsi Lahan: penyesuaian tata guna dan daya dukung lahan terhadap fungsi lahan existing dan lahan potensial untuk dikembangkan sebagai DTW bumi perkemahan.; 3) Zonasi: merupakan pengaturan dan pembagian zona-zona kawasan wisata berdasarkan fungsi pengembangannya dengan klasifikasi zona publik, zona semi publik, zona semi privat, dan zona privat dengan tujuan untuk meningkatkan kualitas keamanan dan kenyamanan dalam berwisata. 


\section{METODE PENELITIAN}

Metode penelitian kualitatif-deskriptif diterapkan untuk menggambarkan secara aktual tentang satu keadaan, dalam hal ini tentang pengembangan wisata Bumi Perkemahan Tangsi Jaya sebagai obyek pengembangan wisata dengan pendekatan Eco Forest Tourism dan River Tourism. Penggunaan pendekatan kualitatif dipilih karena penelitian cenderung menekankan pada kegiatan pengamatan atau observasi di lapangan (Veal, 2017).

Pengumpulan data penelitian menggunakan sumber data primer dan sekunder, sebagai berikut: 1) Data Primer berupa data dari sumber asli untuk tujuan tertentu, terhubung secara langsung dengan obyek penelitian (Nykiel, 2007), dalam hal ini Bumi Perkemahan Tangsi Jaya. Pengumpulan data potensi dan permasalahan wisata perkemahan, serta pola ruang dan tata ruang dilakukan secara langsung melalui observasi dan wawancara. Hasil pengumpulan data tersebut dicatat dan didokumentasikan sebagai acuan dalam memetakan rancangan zonasi dan tata ruang aktivitas dan fasilitas wisata Bumi Perkemahan Tangsi Jaya; 2) Data Sekunder (Nykiel, 2007) data pendukung yang di peroleh dari sumber lain yang atau lewat perantara lain yang berkaitan dengan penelitian, berupa literasi yang terkait dengan penelitian pengembangan wisata sungai (artikel, buku, laporan riset).

\section{HASIL DAN ANALISIS}

\section{Identifikasi Potensi Wisata Bumi Perkemahan Tangsi Jaya}

Kawasan Bumi Perkemahan Tangsi Jaya berlokasi di Kampung Tangsi, Desa Gununghalu, Kecamatan Gununghalu Kabupaten Bandung Barat yang berbatasan langsung dengan wilayah Desa Sindang Kerta sebelah Timur, Desa Cipongkor sebelah Utara, Desa Rongga sebelah Barat, serta Sebelah Selatan Kab. Cianjur. Berikut adalah peta wilayah administrasi tapak kawasan Bumi Perkemahan Tangsi Jaya. Kawasan Bumi Perkemahan Tangsi Jaya memiliki potensi daya tarik wisata yang berada pada hamparan areal perbukitan menyajikan pemandangan pedesaan dengan hutan, perkebunan dan sungai. Perbukitan ini dijadikan sebagai "center of stage" pada kawasan Bumi Perkemahan Tangsi Jaya karena keberadaannya yang ideal sebagai daerah perkemahan. Areal hijau perbukitan ditumbuhi pepohonan khas hutan tropis, terdapat juga aliran sungai Cidadap di bagian dalam. Pedesaan di Kawasan Bumi Perkemahan Tangsi Jaya juga memiliki daya tarik wisata desa yang dapat dikembangkan yaitu aktivitas masyarakat di desa Gununghalu sebagai pembuat gula merah, pengrajin golok, serta pengrajin bambu.

Perkebunan Kopi merupakan salah satu daya tarik kawasan Bumi Perkemahan Tangsi Jaya, tepatnya di Dukuh Tangsi Jaya Desa Gunung Halu. Luas lahan 20 Ha telah menghasilkan buah dan terletak di kawasan hutan lindung Resort Pengelolaan Hutan (RPH), sehingga para petani kopi (tergabung dalam Koperasi Rimba Lestari) mengelola secara bagi hasil dengan pihak PERHUTANI. Jenis kopi yang dibudidayakan adalah Robusta dan Arabika.

Di sekitar Bumi Perkemahan Tangsi Jaya terdapat daya tarik wisata lain seperti Situ Rancabolang (luas danau +/- $2.934 \mathrm{~m} 2$, dengan kedalaman $8 \mathrm{~m}$ ), berada di DAS Cidadap di kawasan Gunung Halu yang alirannya melewati Kawasan Bumi Perkemahan Tangsi Jaya. Aliran sungai tidak terlalu deras dengan variasi landscape yang menarik. Disekitar Bumi Perkemahan Tangsi Jaya terdapat Kebun Teh Montoya milik PT Perkebunan Nusantara VIII. Perkebunan teh ini telah berdiri lebih dari satu abad yang lalu, yaitu pada tahun 1908 dengan nama NV Cultur. Kebun Teh Montoya memiliki luas areal +/- 1.194,00 hektar. Aktivitas pemetik teh, dengan caping lebar dan keranjang di punggung, merupakan suatu suasana yang dapat ditawarkan kepada pengunjung. Kebun Teh Montaya mempunyai keunikan tersendiri dimana wilayah ini membaur dengan areal persawahan.

Curug Cilingga Payung (1276 mdpl) berada di sekitar kawasan Bumi Perkemahan Tangsi Jaya tepatnya di Desa Gunung Halu. Memiliki fitur air terjun berupa tiga tingkatan dengan ketinggian kurang

4 | Jurnal Kepariwisataan: Destinasi, Hospitalitas dan Perjalanan, Volume 5 Nomor 1, 2021: 75-88 
lebih 100 m. Bunga Anggrek merupakan salah satu vegetasi yang banyak ditemukan disekitar Curug Cilingga Payung. Daya tarik lain yaitu Situs Gunung Halu dimana terdapat situs makam yang masih berkaitan dengan keturunan Raja Galuh. Situs Gunung Halu merupakan makam yang paling tua jika dibandingkan dengan makam Prabu Lingga Hiyang dan Prabu Lingga Wastu yang terdapat di Kecamatan Cipatat. Kedua makam tersebut masih merupakan satu keturunan dengan Eyang Gunung Halu.

\section{Aktivitas Wisata}

Aktivitas wisata berkemah (camping) menjadi aktivitas utama dalam areal Bumi Perkemahan Tangsi Jaya. Aktivitas wisata lainnya yang dapat dilakukan di area ini yaitu photography, hammocking, piknik serta aktivitas Outwardbound. Luas kawasan Bumi Perkemahan Tangsi Jaya ini yaitu 2 Ha, dikelola oleh pihak swasta dengan sistem sewa lahan kepada pihak Perum Perhutani KPH Bandung Barat. Biaya untuk berkemah yaitu sekitar Rp. 20.000/orang/malam. Kawasan Bumi Perkemahan Tangsi Jaya menyediakan sarana out bound dan teambuilding dengan wahana flying fox. Aktivitas wisata river tubing tersedia di Bumi Perkemahan Tangsi Jaya dengan memanfaatkan aliran sungai Cidadap. Aktivitas ini dapat dikembangkan untuk segmen keluarga dengan pertimbangan kondisi sungai yang tidak terlalu deras sehingga aman untuk pemula.

Aktivitas wisata lain adalah melihat kehidupan masyarakat Desa Tangsi Jaya dalam pengolahan gula merah, pengolahan bambu dan kerajinan golok. Pada area lain, dapat dikembangkan aktivitas wisata melihat proses pengolahan kopi Gunung Halu yang mulai dikenal oleh masyarakat. Kebun Teh Montoya dapat dikembangkan untuk aktivitas bersepeda, sightseeing, tea walk, dan kegiatan photography. Aktivitas wisata alam trekking dapat dilakukan pada jalur air terjun/curug Cilingga Payung yang dibuat secara swadaya oleh masyarakat.

Di sekitar Bumi Perkemahan Tangsi Jaya terdapat Situs Gunung Halu. Situs sejarah ini dapat dikembangkan menjadi wisata sejarah dan wisata ziarah dengan penyediaan interpretasi dan pemanduan yang memadai mengenai sejarah situs ini dengan sejarah Bandung masa lampau.

\section{Fasilitas Wisata}

Fasilitas wisata yang telah tersedia pada kawasan Bumi Perkemahan Tangsi Jaya adalah lahan parkir, toilet umum dan shelter. Terdapat papan informasi tata tertib pengunjung untuk mengatur pengunjung saat melakukan aktivitas wisata. Fasilitas akomodasi berkemah terdapat juga homestay yang disewakan oleh masyarakat di sekitar kawasan. Fasilitas makan dan minum tersedia warung yang disediakan secara swadaya oleh masyarakat. Belum terdapat fasilitas pertolongan pertama atau klinik kesehatan di Kawasan Bumi Perkemahan Tangsi Jaya.

\section{Aksesibilitas dan Transportasi}

Jarak Bumi Perkemahan Tangsi Jaya dari pusat ibukota kecamatan yaitu sekitar $4.8 \mathrm{~km}$, sedangkan jarak dari pusat kota Bandung sekitar $63 \mathrm{~km}$ dengan waktu tempuh sekitar 2 jam. Untuk mencapai kawasan ini dapat menggunakan kendaraan pribadi dan transportasi umum. Pengunjung dianjurkan menggunakan kendaraan untuk berpenggerak roda $4 \times 4$. Transportasi umum yang dapat digunakan untuk menuju kawasan Bumi Perkemahan Tangsi Jaya yaitu dengan menggunakan elf (minibus) tujuan Gununghalu - Ciwidey tarif Rp. 15.000,00 per orang. Layanan transportasi tersebut tersedia saat pagi sampai pukul 17.00 WIB. Kondisi fisik jalan menuju kawasan Bumi Perkemahan Tangsi Jaya belum dibangun dan dikembangkan dimana sebagian ground cover jalan berupa aspal namun sebagian lainnya masih merupakan bebatuan serta tanah merah. 


\section{Identifikasi Pola Ruang Wilayah (Zonasi) Bumi Perkemahan Tangsi Jaya}

Kawasan Bumi Perkemahan Tangsi Jaya yang berlokasi di Desa Gununghalu, Kecamatan Gununghalu berada pada $7^{\circ} 3^{\prime} 32.25^{\prime \prime}$ LS dan $107^{\circ} 20^{\prime} 22.79^{\prime \prime}$ BT, dengan luas lahan sekitar 2 hektar. Secara foto udara penampakan bentukan fisik alamnya dapat di lihat pada gambar berikut.

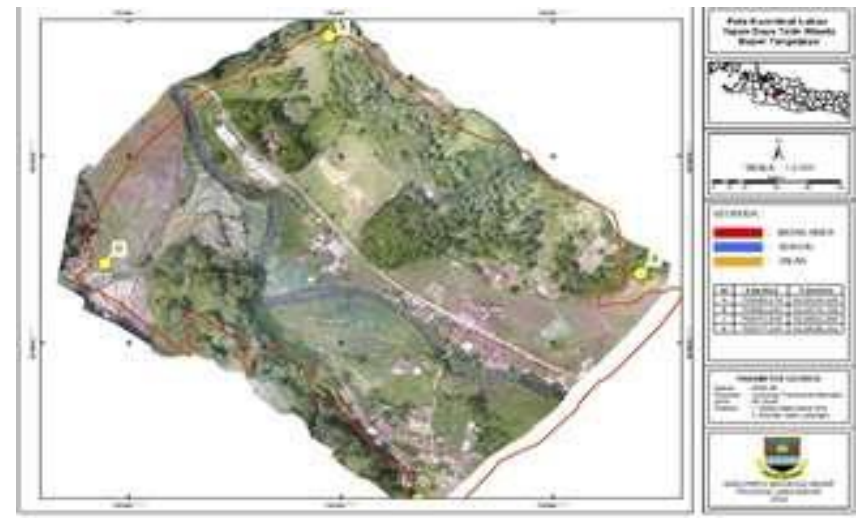

Gambar 1. Peta Kordinat Lahan

Sumber: Dinas PUPR Kabupaten Bandung Barat, 2019

Kawasan Bumi Perkemahan Tangsi Jaya, berada pada ketinggian $1.087 \mathrm{mdpl}$, memiliki bentang alam berupa perbukitan, dataran dan aliran sungai. Kemiringan lahan pada kawasan terdiri dari lereng datar (0-8\%) hingga lereng dengan kemiringan 25-40\% pada areal bukit. Iklim kawasan adalah hangat sedang, dengan rata-rata suhu udara $28,390 \mathrm{C}$ dan rata-rata kelembapan $76 \%$, curah hujan rata-rata 2500 $3000 \mathrm{~mm} /$ tahun. Secara topografi kontur lahan dan ketinggian Kawasan Bumi Perkemahan Tangsi Jaya dapat di lihat pada gambar sebagai berikut.

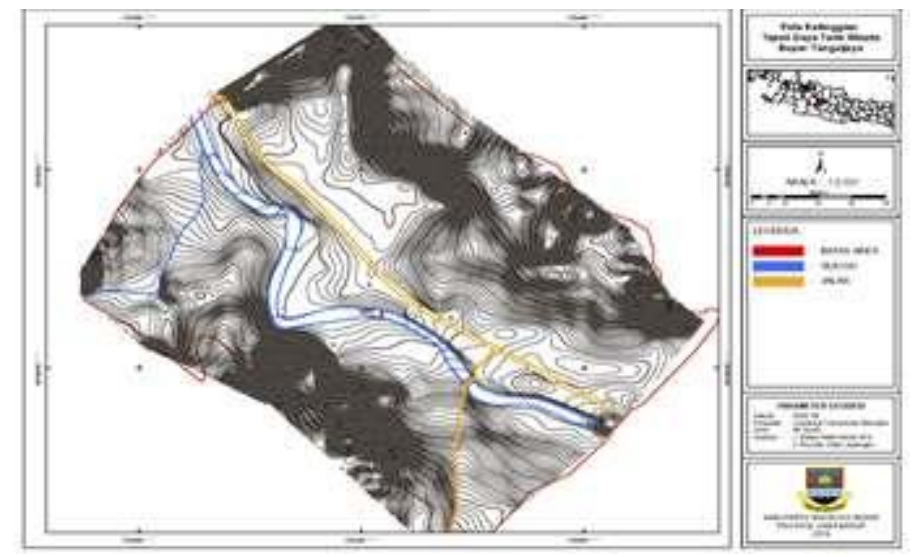

Gambar 2. Peta Ketinggian Bumi Perkemahan Tangsijaya Sumber: Dinas PUPR Kabupaten Bandung Barat, 2019

Kawasan Bumi Perkemahan Tangsi Jaya memiliki vegetasi penutup berupa tanaman produktif yaitu pinus, karet dan kayu keras, sedangkan pada kawasan hutan lindung tertutup vegetasi tanaman heterogen. Tutupan vegetasi ini terbagi pada tanaman yang dikelola secara teratur untuk kepentingan produksi dan tanaman hutan yang digunakan untuk kepentingan pelestarian alam. Pemanfaatan vegetasi

6 | Jurnal Kepariwisataan: Destinasi, Hospitalitas dan Perjalanan, Volume 5 Nomor 1, 2021: 75-88 
di Kawasan Bumi Perkemahan Tangsi Jaya ini digunakan untuk perkebunan, ladang, sawah, hutan kering dan semak belukar, tersaji pada gambar sebagai berikut.

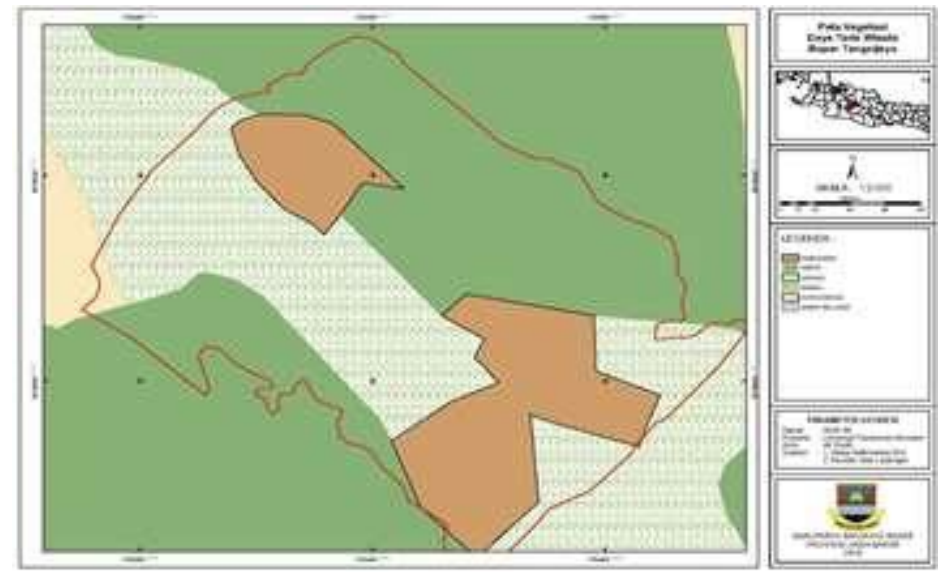

Gambar 4. Peta Vegetasi Bumi Perkemahan Tangsijaya

Sumber: Dinas PUPR Kabupaten Bandung Barat, 2019

Di dalam kawasan Bumi Perkemahan Tangsi Jaya terdapat aliran sungai yang merupakan bagian dari aliran Sungai Cidadap dengan debit air yang cukup deras sepanjang tahun. Kedalaman rata-rata pada kondisi normal antara $0.5 \mathrm{~m}-1.5 \mathrm{~m}$ disertai batuan basalt di sepanjang sungai. Tingkat pencemaran rendah, kondisi air jernih, tidak berbau dan tidak berwarna.

\section{Tata Guna Lahan / Fungsi Lahan}

Fungsi lahan di Kawasan Bumi Perkemahan Tangsi Jaya secara garis besar terbagi menjadi 2 yaitu:

1. Kawasan Lindung: dimiliki oleh negara dan dikelola oleh KPH-BKSDA meliputi kawasan konservasi/bagian dalam Bumi Perkemahan Tangsi Jaya dengan aturan pemanfaatan terbatas untuk kegiatan wisata alam, hutan alami yang difungsikan untuk konservasi alam. Di dalamnya termasuk mata air dan aliran anak sungai Cidadap.

2. Kawasan Budidaya: dimiliki oleh negara yang pengelolaannya dikerjasamakan bersama pihak swasta dan masyarakat untuk digunakan sebagai lahan hutan produktif, kebun dan aktivitas komersial pariwisata. Pada kawasan ini diperkenankan pembangunan fasilitas pendukung ekowisata dan pendukung aktivitas wisata sungai.

Kawasan Bumi Perkemahan Tangsi Jaya memiliki luas 2 Ha dengan kontur dataran landai sesuai dengan fungsi lahan untuk pusat aktivitas pariwisata. Secara umum, kawasan Bumi Perkemahan Tangsi Jaya berada pada klasifikasi kemampuan lahan kategori C (kemampuan pengembangan sedang) dan kategori B (kemampuan pengembangan cukup). Pemanfaatan air tanah untuk keperluan kebersihan pengunjung dilakukan pada area publik, sedangkan pemanfaatan air sungai dapat diperluas untuk aktivitas wisata sungai berupa river tubing.

\section{Zonasi}

Zonasi eksisting di Bumi Perkemahan Tangsi Jaya terdapat pemisahan aktivitas dan pengembangan pariwisata yang dibagi berdasarkan 4 jenis zona, yaitu:

1. Zona Publik: meliputi area pintu masuk, parkir, lobby dan area amenitas depan yang digunakan sebagai pusat aktivitas wisata.

2. Zona Semi Publik: area pengenalan aktivitas wisata digunakan sebagai zona familiarisasi dan penyerapan kepadatan di area publik.

3. Zona Semi Privat: area perantara yang digunakan untuk aktivitas wisata intensitas ringan.

4. Zona Privat: area yang digunakan untuk aktivitas wisata khusus dengan kepadatan rendah. 


\section{Identifikasi Tata Ruang Aktivitas dan Fasilitas Wisata Bumi Perkemahan Tangsi Jaya}

Untuk dapat mengidentifikasi kondisi tata ruang aktivitas dan fasilitas wisata di Bumi Perkemahan Tangsi Jaya dapat dilihat pada gambar 5 yang kemudian akan dijelaskan lebih lanjut terkait pola sirkulasi, jalur wisata, serta aktivitas dan fasilitas eksisting.

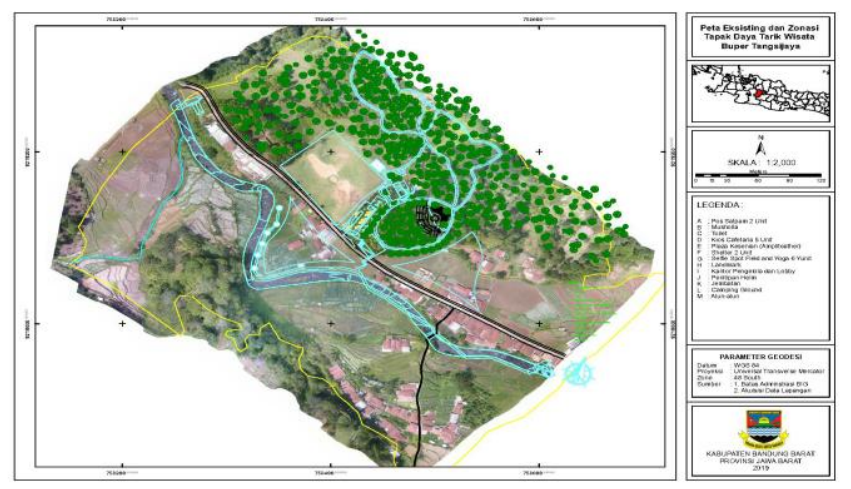

Gambar 5. Peta Kondisi Eksisting Pola Tata Ruang Aktivitas dan Fasilitas Wisata Sumber : Dinas PUPR Kab Bandung Barat, 2019

\section{Sirkulasi}

Kondisi eksisting terkait sirkulasi Kawasan Bumi Perkemahan Tangsi Jaya dimulai dari area luar tapak yang berupa akses jalan menuju area tapak, yaitu Jalan Lebakmuncang, Ciwidey, Jawa Barat. Jika menggunakan akses dari Soreang yang merupakan ibukota Kabupaten Bandung, maka untuk menuju area tapak adalah dengan melalui Jalan Raya Soreang-Ciwidey, kemudian Jalan Ciwidey-Cibeber, lalu memasuki area Cisedet, dan masuk melalui Jalan Lebakmuncang. Dilihat dari peta diatas, arah masuk menuju area dalam tapak adalah dari arah timur peta, melalui jalan Lebakmuncang, kemudian dilanjut ke area tengah yang merupakan pintu masuk Kawasan Bumi Perkemahan Tangsi Jaya.

Adapun bangunan pertama yang ditemui setelah pintu masuk kawasan adalah pos penjagaan/satpam dan loket tiket, yang berada tepat disebelah kanan area parkir sepeda motor, bangunan ini ditandai dengan huruf A pada peta diatas.

Setelah melalui pos penjagaan, bangunan selanjutnya yang dijumpai adalah jajaran kios cafetaria, bangunan-bangunan tersebut berada disepanjang arah utara pos penjagaan dan loket tiket. Disebelah kanan dan kiri jalan menuju arah utara, terdapat playground yang dapat memfasilitasi aktivitas bermain anak. Pada peta kondisi eksisting diatas, jajaran kios cafetaria ditandai dengan huruf D. Arah barat dari jajaran kios penduduk, terdapat bangunan toilet dan mushola.

\section{Jalur Wisata}

Terdapat 2 pola pergerakan pengunjung di Kawasan Bumi Perkemahan Tangsi Jaya sebagai berikut.

Pola pertama merupakan pola pergerakan pengunjung/wisatawan yang melakukan one-day trip. Pergerakan pengunjung dimulai dari pintu masuk untuk kemudian membeli tiket masuk Kawasan, dan dilanjut untuk melakukan aktivitas-aktivitas di area utara dan selatan dari pos penjagaan dan loket tiket. Adapun aktivitas yang dapat dilakukan di area utara meliputi games, outbond, permainan anak, berswafoto (selfie) maupun istirahat dan ibadah. Selain area utara, terdapat pula area selatan yang menawarkan aktivitas berupa tubing/susur sungai bagi pengunjung yang melakukan one-day trip di Kawasan Bumi Perkemahan Tangsijaya.

Pola kedua merupakan pola pergerakan pengunjung/wisatawan yang melakukan aktivitas lebih dari satu hari. Pola pergerakan pengunjung ini dimulai dari pintu masuk, membeli tiket masuk Kawasan

8 | Jurnal Kepariwisataan: Destinasi, Hospitalitas dan Perjalanan, Volume 5 Nomor 1, 2021: 75-88 
dan tiket berkemah di loket tiket. Pola ini akan langsung melakukan aktivitas di area berkemah yang berlokasi di arah barat laut dari pos penjagaan, area berkemah.

\section{Aktivitas dan Fasilitas}

Kondisi aktivitas kegiatan dan fasilitas eksisting meliputi: 1) Kondisi eksisting terkait aktivitas dan fasilitas utama di Bumi Perkemahan Tangsi Jaya saat ini diantaranya aktivitas ber-swafoto (selfie) dengan fasilitas berupa beberapa spot foto sederhana, berkemah dengan fasilitas camping ground, permainan ketangkasan dengan fasilitas berupa instalasi outbond, dan river tubing; 2) Aktivitas dan fasilitas pendukung yang ada saat ini meliputi mushola, toilet, gerbang pintu masuk, kantor pengelola, kios - kios makan minum, lapangan parkir dengan kondisi semuanya kurang terawat dan kurang tertata; 3) Aktivitas dan fasilitas penunjang lainnya terdapat fasilitas jembatan untuk melintas menuju hutan. Adapun fasilitas jembatan tersebut pernah rubuh karena daya tampung pengunjung yang melebihi kapasitas selain itu juga memang kondisi jembatan tersebut sudah usang.

\section{Analisis Pola Ruang Wilayah (Zonasi)}

\section{Analisis Fisik Alam}

Merupakan analisis kesesuaian antara topografi, klimatologi, geologi, hidrologi yang mendukung pengembangan Bumi Perkemahan Tangsi Jaya sebagai destinasi wisata Eco Forest Tourism and River Camp Bumi Perkemahan Tangsi Jaya yang tidak merusak alam dan ekosistemnya.

Dengan memperhatikan kontur lahan Bumi Perkemahan Tangsi Jaya berupa dataran landai dan perbukitan dengan kemiringan rata-rata $20 \%$ dilengkapi aliran sungai sebagai pengikat pandangan, kawasan ini sangat sesuai dikembangkan sebagai kawasan wisata berbasis lingkungan (ekowisata) dengan aktivitas utama trekking, camping dan river tubing. Memanfaatkan vegetasi penutup berupa tanaman pinus, karet dan tanaman hutan alamiah menjadikan kawasan ini nyaman untuk aktivitas wisata berbasis alam. Aktivitas trekking dapat dikembangkan dengan konten edukasi botani atau pengenalan ekosistem hutan dan ekosistem sungai.

Kawasan ini memiliki curah hujan rata-rata 2500 - 3000 mm/tahun, serta keberadaan mata air dan hutan lindung di sekitar kawasan menjadikan debit air sungai di Bumi Perkemahan Tangsi Jaya dapat digunakan sepanjang tahun. Mempertimbangkan kondisi tersebut dan kedalaman rata-rata sungai, penyediaan layanan pemanduan pengarungan sungai yang sesuai diselenggarakan adalah aktivitas river tubing dan rafting.

\section{Analisis Lahan (Tata Guna Lahan / Fungsi Lahan)}

Merupakan analisis penyesuaian tata guna dan daya dukung lahan terhadap fungsi lahan existing dan lahan potensial untuk dikembangkan sebagai DTW bumi perkemahan Eco Forest Tourism and River Camp. Pemanfaatan lahan dilakukan dengan pertimbangan sebagai berikut:

1. Lahan Konservasi: lahan hutan lindung yang digunakan sebagai sanctuary zone, dimanfaatkan untuk aktivitas wisata terbatas berupa jungle trekking dengan menyusuri bagian pinggiran hutan. Bagian dalam tidak digunakan untuk aktivitas wisata massal, dapat dibuka dengan pembatasan jumlah dan aktivitas yang ketat.

2. Lahan Budidaya: lahan pada bagian ini difungsikan sebagai pusat pengembangan aktivitas dan fasilitas wisata. Tema aktivitas dan fasilitas dikembangkan konsep ekowisata serta wisata sungai sehingga tidak memiliki kesenjangan dengan tema umum kawasan.

Untuk melindungi kelestarian kawasan, pengembangan ekowisata dan wisata sungai dapat dikembangkan berdasarkan klaster aktivitas yaitu massal dan individual. Aktivitas wisata massal dapat dikembangkan pada area depan dan area perkemahan utama, sedangkan aktivitas wisata individual 
dikembangkan hingga ke pinggiran kawasan hutan lindung. Pemisahan aktivitas ini juga untuk meningkatkan keamanan, kenyamanan dan optimalisasi pengalaman wisata di Bumi Perkemahan Tangsi Jaya.

\section{Analisis Lahan (Tata Guna Lahan / Fungsi Lahan)}

Merupakan analisis penyesuaian tata guna dan daya dukung lahan terhadap fungsi lahan existing dan lahan potensial untuk dikembangkan sebagai DTW bumi perkemahan Eco Forest Tourism and River Camp.

Pemanfaatan lahan dilakukan dengan pertimbangan sebagai berikut:

1. Lahan Konservasi: lahan hutan lindung yang digunakan sebagai sanctuary zone, dimanfaatkan untuk aktivitas wisata terbatas berupa jungle trekking dengan menyusuri bagian pinggiran hutan. Bagian dalam tidak digunakan untuk aktivitas wisata massal, dapat dibuka dengan pembatasan jumlah dan aktivitas yang ketat.

2. Lahan Budidaya: lahan pada bagian ini difungsikan sebagai pusat pengembangan aktivitas dan fasilitas wisata. Tema aktivitas dan fasilitas dikembangkan konsep ekowisata serta wisata sungai sehingga tidak memiliki kesenjangan dengan tema umum kawasan.

Untuk melindungi kelestarian kawasan, pengembangan ekowisata dan wisata sungai dapat dikembangkan berdasarkan klaster aktivitas yaitu massal dan individual. Aktivitas wisata massal dapat dikembangkan pada area depan dan area perkemahan utama, sedangkan aktivitas wisata individual dikembangkan hingga ke pinggiran kawasan hutan lindung. Pemisahan aktivitas ini juga untuk meningkatkan keamanan, kenyamanan dan optimalisasi pengalaman wisata di Bumi Perkemahan Tangsi Jaya.

\section{Analisis Zonasi}

Merupakan analisis pengaturan dan pembagian zona-zona kawasan wisata berdasarkan fungsi pengembangannya dengan klasifikasi zona publik, zona semi publik, zona semi privat, dan zona privat dengan tujuan untuk meningkatkan kualitas keamanan dan kenyamanan dalam berwisata

Pengembangan pariwisata dengan menggunakan konsep zonasi di Bumi Perkemahan Tangsi Jaya dapat diuraikan sebagai berikut:

1. Zona Publik: pemanfaatan area masuk kawasan dengan upaya perkerasan jalan dan lahan untuk sarana parkir, gerbang, kantor pengelola depan, landmark, kios dan WC umum. Pada daerah ini dimungkinkan aktivitas wisata dengan kepadatan tinggi, dengan tetap memperhatikan kebersihan dan kelestarian lingkungan.

2. Zona Semi Publik: area ini digunakan sebagai penyangga zona publik untuk menyerap kepadatan dengan membuat kantong aktivitas ringan berupa sarana swa-foto, area istirahat dan area edukasi kawasan. Pada zona ini dimungkinkan pembangunan fasilitas pendukung dengan tema dan bahan ramah lingkungan.

3. Zona Semi Privat: area yang berada pada bagian tengah kawasan ditutupi oleh vegetasi rumput, pinus dan karet dapat digunakan untuk aktivitas wisata sightseeing, river tubing, camping, halang rintang (outbound games) dan trekking.

4. Zona Privat: area yang digunakan untuk aktivitas wisata khusus dengan kepadatan rendah yaitu river side camping dan jungle trekking. 


\section{Analisis Tata Ruang Aktivitas dan Fasilitas Wisata Bumi Perkemahan Tangsi Jaya Analisis Sirkulasi Pengunjung}

Sirkulasi Bumi Perkemahan Tangsi Jaya dimulai dari area luar tapak yang berupa akses jalan menuju area tapak, yaitu Jalan Lebakmuncang, Ciwidey, Jawa Barat. Jika menggunakan akses dari Soreang yang merupakan ibukota Kabupaten Bandung, maka untuk menuju Kawasan Bumi Perkemahan Tangsi Jaya adalah dengan melalui Jalan Raya Soreang-Ciwidey, kemudian Jalan Ciwidey-Cibeber, lalu memasuki area Cisedet, dan masuk melalui Jalan Lebakmuncang.

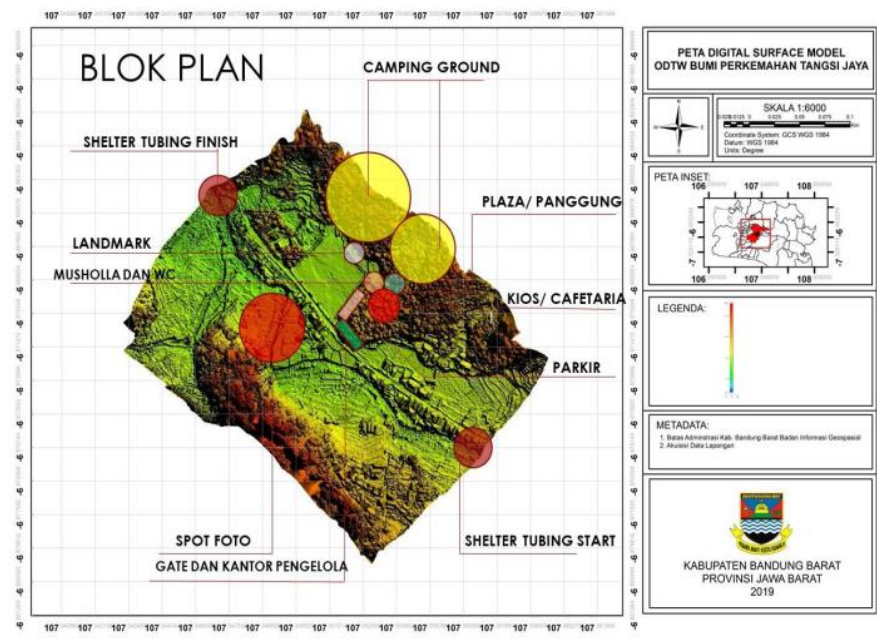

Gambar 6. Blok Plan Bumi Perkemahan Tangsijaya

Sumber: Dinas PUPR Kab Bandung Barat, 2019

Dilihat dari gambar 6 peta blok plan, arah masuk menuju Kawasan Bumi Perkemahan Tangsi Jaya adalah dari arah timur peta (berdekatan dengan shelter tubing start), melalui jalan Lebakmuncang, kemudian dilanjutkan ke area tengah yang merupakan pintu masuk area Bumi Perkemahan Tangsi Jaya.

Bangunan pertama yang ditemui setelah pintu masuk kawasan adalah loket tiket dan kantor pengelola, yang berada tepat disebelah kanan area parkir. Kemudian disisi kiri dan kanan jalur utama akan diisi lahan hijau dengan vegetasi alami kawasan, hal ini dimaksudkan untuk menjaga keaslian lingkungan dengan memindahkan bangunan-bangunan kios penduduk dan spot foto sesuai dengan zonasinya.

Pada penghujung jalur utama, disebelah kanan akan diisi oleh jajaran kios cafetaria dan plaza kesenian. Bangunan-bangunan kios sebelumnya berada disepanjang sisi jalur utama pintu masuk dengan letak yang tidak tertata. Sentralisasi kios-kios ini dilakukan untuk memudahkan pengunjung yang ingin menikmati makanan dan minuman di Kawasan Bumi Perkemahan Tangsi Jaya. Adapun bangunan tambahan pada area ini berupa plaza kesenian, hal ini dimaksudkan untuk meningkatkan kenyamanan pengunjung saat beristirahat di area cafetaria.

Pada sisi kiri di penghujung jalur utama, terdapat musholla dan toilet dengan bentuk bangunan baru yang selaras dengan karakteristik alam Bumi Perkemahan Tangsi Jaya. Selanjutnya, terdapat penambahan bangunan di area sisi kiri jalur utama berupa sebuah landmark, area ini sebelumnya merupakan lapangan yang pemanfaatannya hanya sebatas fasilitas olahraga masyarakat. Landmark ini dimaksudkan sebagai bentuk nyata identitas kawasan Bumi Perkemahan Tangsi Jaya.

Selain bangunan-bangunan di atas, terdapat tiga bangunan baru lainnya, dua bangunan berupa shelter untuk aktivitas tubing atau susur sungai yang berada diujung timur dan barat area dalam tapak. Bangunan lainnya berupa spot foto dan yoga yang berada di arah selatan pintu masuk kawasan. Pemindahan area spot foto dilakukan sebagai upaya memaksimalkan potensi lahan di selatan area tapak. 
Adapun bangunan spot foto dan yoga yang direncanakan berupa bangunan semi-permanen, yang akan selaras dengan lingkungan persawahan saat ini.

Jalur sirkulasi pejalan kaki dan kendaraan tersaji pada gambar 7 dan 8 sebagai berikut.

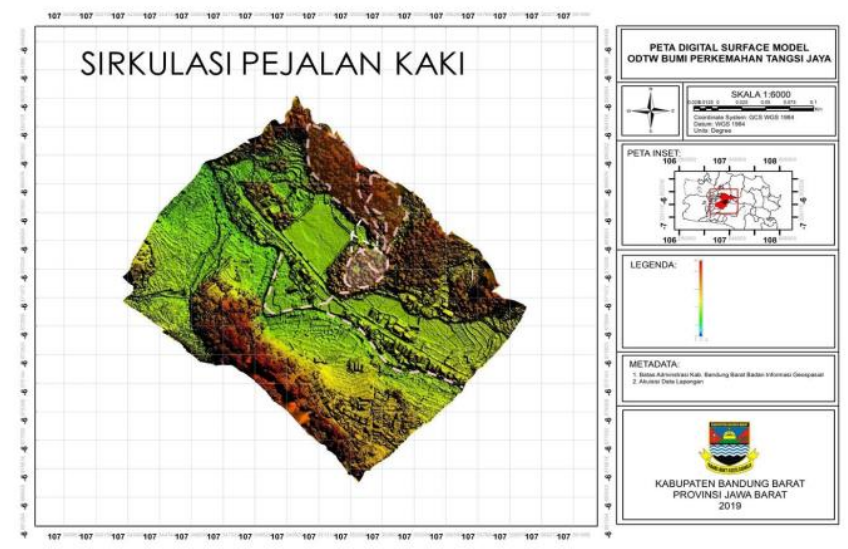

Gambar 7. Peta Sirkulasi Pejalan Kaki

Sumber: Dinas PUPR Kab Bandung Barat, 2019

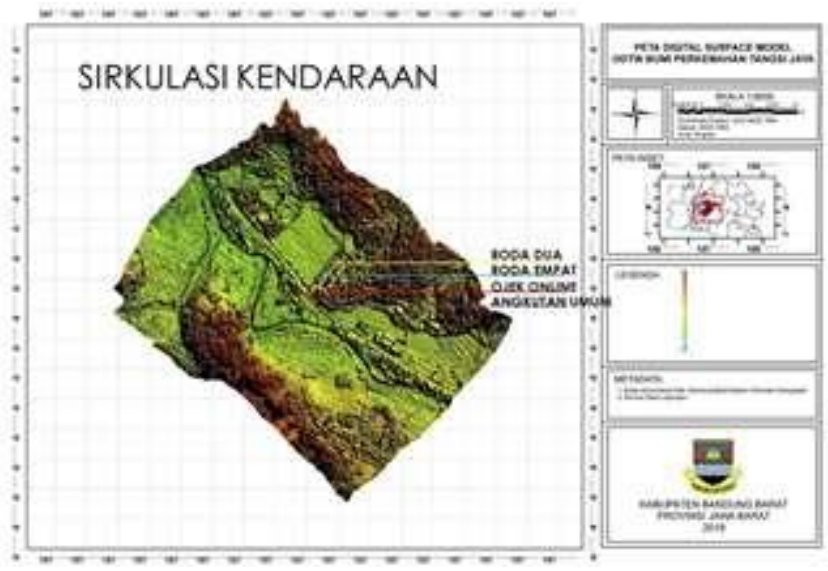

Gambar 8. Peta Sirkulasi Kendaraan

Sumber: Dinas PUPR Kab Bandung Barat, 2019

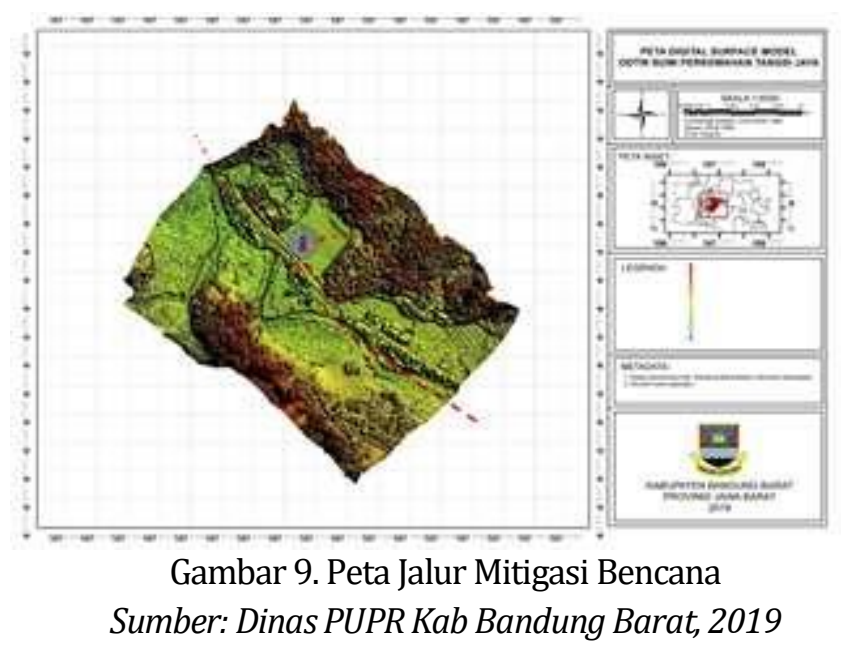

Selain sirkulasi untuk pejalan kaki dan kendaraan, terdapat juga rencana pembuatan jalur mitigasi yang bertujuan sebagai jalur evakuasi jika terjadi resiko bencana alam di kawasan Buper Tangsijaya. Jalur mitigasi tersaji pada gambar 9 sebagai berikut. 


\section{E. SIMPULAN}

Mempertimbangkan potensi sumber daya wisata yang dimiliki, aktivitas wisata yang dapat dikembangkan dengan konsep ekowisata bertema River Side Camp and Eco Forest Tourism dengan pengembangan aktivitas dan fasilitas wisata yang linear dengan klaster utama, pendukung dan penunjang.

Memperhatikan kondisi bentang alam dan pertimbangan ekologis lainnya, Bumi Perkemahan Tangsi Jaya dikembangkan dengan konsep ekowisata bertema River Side Camp and Eco Forest Tourism dengan membagi menjadi 4 zona dengan konsep zona inti - zona penyangga sebagai berikut: 1) Zona Publik: pusat kedatangan-kepulangan, memiliki kepadatan paling tinggi, digunakan untuk penyediaan fasilitas umum; 2) Zona Semi-Publik: daerah penyangga untuk membagi kepadatan di area public, digunakan untuk aktivitas familiarisasi dan edukasi pengunjung; 3) Zona Semi Privat: digunakan sebagai penyangga zona privat, berisi aktivitas wisata ringan. 4) Zona Privat: inti kawasan digunakan sebagai pusat aktivitas wisata khusus dan zona konservasi.

Penelitian ini telah memberikan alternatif konsep pengembangan destinasi wisata bernuansa lingkungan pada jalur alternatif Bandung Raya. Hasil penelitian ini dapat dikembangkan pada tingkat yang lebih teknis yaitu tata letak fasilitas, perencanaan program pengelolaan dan kelayakan investasi.

\section{DAFTAR REFERENSI}

Beritelli, P., \& Laesser, C. (2017). The Dynamics Of Destinations And Tourism Development. Design Science In Tourism (hal. 195-214). Springer, Cham.

Cimbaljević, M., Stankov, U., \& \& Pavluković, V. (2019). Going Beyond The Traditional Destination Competitiveness-Reflections On A Smart Destination In The Current Research. Current Issues in Tourism, 2472-2477.

Conway, J. (2002). Evaluation Of Wilderness And Adventure Therapy Programs For Young People. Victoria, Australia: T. O. E. J. S. Services.

Cooper, M., \& Pridaux, B. (2005). Conclusion And Challenges, Ritsumeikan Asian Pacific University, Beppu, Japan. Cairns, Australia: James Cook University.

Cracolici, M. F., \& Nijkamp, P. (2009). The Attractiveness And Competitiveness Of Tourist Destinations: A Study Of Southern Italian Regions. Tourism Management, 336-344.

Hsueh, I.-C., \& Lai, M.-J. (2000). Resource Evaluation Of Candidate Site Selection For Forest Recreation. Tung Hai Journal, 111-132.

Jacobsen, K. I., Lester, S. E., \& \& Halpern, B. S. (2014). A Global Synthesis Of The Economic Multiplier Effects Of Marine Sectors. Marine Policy, 273-278.

Jianxiong, Q., Z. Pei, D. G., \& Lu, C. (2014). A Study On Eco-Tourism And Sustainable Development Of Economic. Northwest China: Smart Grid, 170-179.

Karayilan, E., \& Cetin, G. (2016). Tourism Destination: Design Of Experiences. The Handbook Of Managing And Marketing Tourism Experiences. Emerald Group Publishing Limited.

Lee, C. F., Huang, H. I., \& Yeh, H. R. (2010). Developing An Evaluation Model For Destination Attractiveness: Sustainable Forest Recreation Tourism In Taiwan. Journal of Sustainable Tourism, 811-828.

Lo, M. C., Chin, C. H., \& Law, F. Y. (2019). Tourists' Perspectives On Hard And Soft Services Toward Rural Tourism Destination Competitiveness: Community Support As A Moderator. Tourism and Hospitality Research, 139-157. 
Murphy, W. (2006). Forest Recreation In A Commercial Environment. Small-Scale Forestry And Rural Development: The Intersection Of Ecosystems, Economics And Society.

Nykiel, R. A. (2007). Handbook Of Marketing Research Methodologies For Hospitality And Tourism. Routledge.

Prideaux, B., \& Cooper, M. (2009). River Tourism. Cabi.

Prideaux, B., \& Cooper, M. (2009). River Tourism. Wallingford: CAB International.

Romão, J., Neuts, B., Nijkamp, P., \& Shikida, A. (2007). Determinants Of Trip Choice, Satisfaction And Loyalty In An Eco-Tourism Destination: A Modelling Study On The Shiretoko Peninsula, Japan. Ecological Economics, 195-205.

UNWTO. (2006). Seminar On Tourism Sustainability And Local Agenda 21 In Tourism. Madrid.

UNWTO. (2007). Practical Guide to Tourism Destination Management. Madrid: UNWTO.

Veal, A. J. (2017). Research Methods For Leisure And Tourism. UK: Pearson .

Wahid, A. Y., \& SH, M. S. (2016). Pengantar Hukum Tata Ruang. Prenada Media.

Williams, P., \& Ponsford, I. (2009). Confronting Tourism's Environmental Paradox:Transitioning For Sustainable Tourism. Futures, 396-404.

Zatori, A., Smith, M. K., \& Puczko, L. (2018). Experience-Involvement, Memorability And Authenticity: The Service Provider's Effect On Tourist Experience. Tourism Management, 111-126.

Zhu, Y. L., Ness, D. A., Xing, K., Schneider, K., Lee, S. H., \& Ge, J. (2015). Alternative Energy Development In Rural Chinese Communities. Transforming Rural Communities In China And Beyond (hal. 93116). Springer, Cham. 